\title{
Pentanoik ve Bütanoik Asit Varlığında Kalsiyum Laktat Sulu Çözeltilerinin Metastabil Bölge Genişliğinin Yeni Yaklaşımlarla İncelenmesi
}

\author{
Analysis of Metastable Zone Width of Calcium Lactate Aqueous Solutions with New Approaches \\ in the Presence of Pentanoic and Butanoic Acid \\ Berçem KIRAN-YILDIRIM1 ${ }^{1}$, Aybala GENÇASLAN ${ }^{1}$ (D), Sibel TITIZ-SARGUT ${ }^{1}(\mathbb{D}$ \\ ${ }^{1}$ Marmara Üniversitesi, Kimya Mühendisliği Bölümü, 34722, Istanbul, Türkiye
}

Öz

Kalsiyum laktat sulu çözeltilerinin politermal yöntem kullanılarak belirlenen metastabil bölge genişliği üzerine soğutma hızının, Pentanoik ve Bütanoik asit varlığının etkisi self-consistent Nývlt-like eşitliği ve klasik üç boyutlu nükleasyon teorisine dayanan yeni bir yaklaşım kullanılarak değerlendirilmiştir. Değerlendirmeler sonucunda nükleasyon kinetik parametreleri olan görünür nükleasyon mertebesi, m, ve nükleasyon sabiti, K, ve safsızlık etkinlik faktörü, $a_{\text {eff, }}$ tespit edilmiştir. Saf ortamda ani nükleasyon mekanizması ile nüklei oluşumu söz konusu iken Pentanoik ve Bütanoik asit varlığında nüklei oluşum mekanizmasının değiştiği ve nükleilerin progresif nükleasyon mekanizması ile oluştuğu ortaya konulmuştur. Katkı maddesi olarak seçilen Pentanoik ve Bütanoik asitin büyüme ünitelerinin büyüyen nükleiye entegrasyonunu destekledikleri ve Bütanoik asitin bu entegrasyonda daha etkin olduğu tespit edilmiştir.

Anahtar Kelimeler: Metastabil bölge genişliği, nükleasyon, nükleasyon kinetiği, kalsiyum laktat pentahidrat, yağ asitleri

\begin{abstract}
The influence of cooling rate and the presence of pentanoic and butanoic acids on metastable zone width (MSZW) of calcium lactate aqueous solutions determined by polythermal method was evaluated by applying the self-consistent Nývlt-like equation and the novel equation of three-dimensional (3D) nucleation theory. As a result of the evaluations, nucleation kinetic parameters; the apparent nucleation order, $\mathrm{m}$ and nucleation constant, $\mathrm{K}$ and effectiveness parameter for the impurity, $\mathrm{a}_{\text {eff }}$ were determined. It has been revealed that the formation of nuclei changed in the presence of pentanoic and butanoic acids and Nuclei were formed by a progressive nucleation mechanism while the nuclei borned by instantenous nucleation mechanism. It has been revealed that while the nuclei are borned by instantenous nucleation mechanism in pure media, the mechanism of nuclei formation is changed in the presence of pentanoic and butanoic acids and nuclei are formed by a progressive nucleation mechanism. It was determined that pentanoic and butanoic acids selected as additives favoured the integration of growth units to growing nuclei and butanoic acid is more effective in this integration.
\end{abstract}

Anahtar Kelimeler: Metastable zone width, nucleation, nucleation kinetic, calcium lactate pentahydrate, fatty acids

\section{GIIRIŞ}

Kalsiyum laktat, laktik asitin bir tuzu olup gıda sektöründe E327 kodlu katkı maddesi olarak kullanılmaktadır. Gıda sanayinde kalsiyum laktat şekerli yiyeceklere diş çürümelerini engellemek amacıyla ilave edilmesinin yanında, taze doğranmış meyvelerin tazeliğini korumak ve raf ömrünü uzatmak amacıyla acı bir tad bırakan kalsiyum klorür yerine de kalsiyum kaynağı olarak kullanılmaktadır [1,2]. Kalsiyum laktatın diğer kalsiyum kaynaklarına göre tercih edilmesinin başta gelen sebepleri çözünürlüğünün oldukça yüksek ve biyoyararlılığının fazla olmasıdır [3]. Kullanım alanlarının başında kalsiyum eksikliğinde ortaya çıkan, kemik kaybının (osteoporoz), zayıf kemiklerin oluşumunun (osteomalazi/rikets), paratiroid bezinin (hipoparatiroidizm) aktivitesinin azalmasının ve ortaya çıkan çeşitli kas hastalıklarının önlenmesinde veya tedavisinde ilaç olarak kullanılması gelmektedir. Yeterli kalsiyum alımı yapması gereken hamileler, postmenopozal kadınlar, fenitoin, fenobarbital veya prednizon gibi bazı ilaçları alan kişiler tarafından kalsiyum takviyesini sağlamak amacı ile kullanılmaktadır. Endüstriyel 
olarak üretilen kalsiyum laktatın ise yollarda buzlanmayı engellemede, çimento kurumasında hızlandırıcı olarak kullanıldığı farklı sektörler bulunmaktadır. Kalsiyum laktat ticari olarak değerli bir ürün olmasına rağmen; süt bileşimi, peynir üretim prosedürleri, peynir mikroflorası, paketleme ve olgunlaştırma sıcaklığ gibi çeşitli nedenlerin kompleks etkileşimi sonucu peynir yüzeyinde oluştuğu düşünülen kalsiyum laktat kristallerinin peynirin diş görünüşünde neden olduğu değişiklik tüketiciyi olumsuz olarak etkilemektedir [4]. Kalsiyum laktatın bu istenmeyen oluşumunun önüne geçilmesi ve diğer sektörlerde kullanılmak üzere üretilecek olan kalsiyum laktatın istenilen nitelikte olması için kristalizasyon kinetiğinin incelenmesi gerekmektedir. Kristalizasyon kinetiği, kristal bir ürünün saflığını ve tane boyut dağılımını doğrudan etkileyen mekanizmalar olan nükleasyon ve kristal büyüme hız kademelerinin belirlenmesi ile ortaya konulmaktadır. Bir kristalizasyon prosesinde her iki kademe için itici güç aşırı doygunluk olup, her çözelti metastabil bölge genişliği (MSZW) olarak tanımlanan maksimum aşırı doygunluk seviyesine sahiptir. Bu nedenle metastabil bölge genişliğinin bilinmesi kristalizasyon prosesinin kontrolü ve istenilen özelliklerde kristal ürün eldesi bakımından oldukça önemlidir. Sıcaklık, karıştırma hızı ve safsızlıkların varlığı gibi faktörlere bağlı olan MSZW üzerine safsızlıkların etkisi belirgin bir mekanizma ile açıklanamamakla birlikte literatürde safsızlık ve/veya katkı maddelerinin aşırı doygun çözeltinin stabilitesini etkilediği, kristallerin yüzey özelliklerini değiştirerek nükleasyon ve kristal büyüme hızlarını, kristallerin morfolojilerini değiştirebildiği belirtilmektedir [5]. Literatürde MSZW üzerine yapılan çalışmalar yaygın olarak Nyvlt tarafindan önerilen politermal yönteme göre yapılmış ve sonuçlar Eşitlik (1) kullanılarak değerlendirilmiştir. Ancak, bu eşitlikteki nükleasyon hız mertebesi, $m$, ve oldukça komplike birime sahip olan nükleasyon hız sabiti $\mathrm{k}_{\mathrm{n},}$ parametrelerinin fiziksel önemleri ortaya tam olarak konulamamıştır. Ayrıca bu parametrelerin klasik 3D nükleasyon teorisi ile yeterli bağlantısı bulunmamaktadır. Yakın zamanda, Sangwal, metastabil bölge genişliği verilerine dayanarak nükleasyon kinetiğini açıklamak için, self-consistent Nývlt-like eşitliği ve üç-boyutlu nükleasyon teorisinin yeni eşitliği olmak üzere iki yeni yaklaşım öne sürmüştür [6,7]." Self-consistent Nývlt-like eşitliği ile nükleasyon hız mertebesi ve nükleasyon sabiti parametresinin fiziksel önemleri ortaya konulabilirken, klasik üç boyutlu nükleasyon teorisine dayanan yaklaşım ile de safsızlıkların etkisi ayrıntılı olarak açıklanabilmektedir.

$\mathrm{Bu}$ çalışmada, kalsiyum laktatın nükleasyon kinetiğinin belirlenmesi amaciyla politermal yöntemle belirlenen kalsiyum laktat sulu çözeltilerinin metastabil bölge genişliği [8] self-consistent Nývlt-like eşitliği ve klasik üç boyutlu nükleasyon teorisine dayanan yeni yaklaşım kullanılarak değerlendirilmiştir. Soğutma hızının ve katkı maddelerinin MSZW üzerine etkilerinin incelendiği bu çalışmada katkı maddesi olarak birçok peynir bileşiminde bulunan ve özellikle süt yağının bileşen olarak kullanıldığı gıdalarda ürüne belirgin bir tat katan kısa zincirli yağ asitleri olan Pentanoik ve Bütanoik asitler kullanılmıştır.

\section{MATERYAL VE YÖNTEM}

Kalsiyum laktat sulu çözeltilerinin metastabil bölge genişliğine farklı soğutma hızlarının $(4,2 \mathrm{~K} / \mathrm{h}, 9,6 \mathrm{~K} / \mathrm{h}, 15,0 \mathrm{~K} / \mathrm{h}$, $30,0 \mathrm{~K} / \mathrm{h}$ ) ve Pentanoik ve Bütanoik asitlerin farklı konsantrasyonlarının $(10,25,50$ ve $100 \mathrm{ppm})$ etkisi incelenmiştir. Politermal metot kullanılarak yapılan ölçümlerde Şekil 1'de gösterilen deney düzeneği kullanılmıştır.

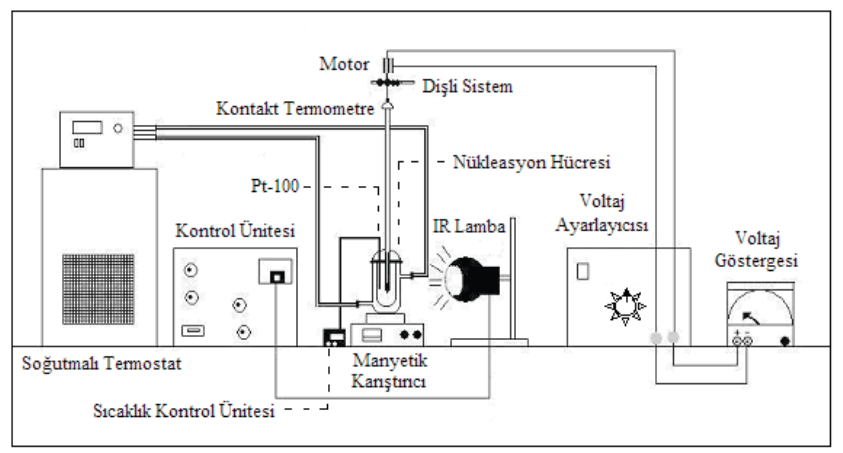

Şekil 1. Metastabil bölge genişliği ölçüm deney düzeneği

Kalsiyum laktat çözeltileri Merck firmasından temin edilen kalsiyum L-laktat pentahidrat kullanılarak 303 $\mathrm{K}^{\prime}$ de $\left(30 \pm 0,1{ }^{\circ} \mathrm{C}\right)$ doygun olacak şekilde hazırlanmış ve elde edilen çözelti $0,45 \mathrm{~mm}$ por çapına sahip filtreden süzülmüştür. Hazırlanan çözelti, aktif hacmi $80 \mathrm{~mL}$ olan nükleasyon hücresine konulmuş ve lineer soğutma hızında soğutulmuştur. Lineer soğutma hızı kontakt termometre ile birlikte çalışan bir motor, bir dişli, bir soğutmalı termostat ve bir IR-Lambanın kullanımı ile sağlanmıştır. Nükleasyon hücresinin iç sıcaklığı, sıcaklık kontrol ünitesine bağlı Pt-100 ile ölçülmüştür. Karıştırma işlemi bir manyetik karıştırıcı yardımı ile $330 \mathrm{rpm}$ sabit karıştırma hızında yapılmıştır. Nükleasyon hücresinin içerisinde kristallerin görünmeye başladığı ilk sıcaklık nükleasyon sıcaklığı olarak belirlenmiştir. Metastabil bölge genişliği (maksimum aşırı soğuma, $\Delta T_{\text {mak }}$ ), nükleasyon sıcaklığ $1\left(T_{\text {nük }}\right)$ ile doygunluk sıcaklığı $\left(T_{0}\right)$ arasındaki farktır. Politermal yöntem ile saptanan metastabil bölge genişliği $\left(\Delta T_{\text {mak }}\right)$ ile soğutma hızı $(R)$ arasındaki ilişkiyi Nývlt aşağıdaki eşitlikle göstermiştir [6]. 
$\log \Delta T_{\text {mak }}=\frac{1-m}{m} \log \left(\frac{d c}{d \tau}\right)-\frac{\log h_{n}}{m}+\frac{1}{m} \log R$

Eşitlikte, $m$, nükleasyon mertebesi, $k_{\mathrm{n},}$ nükleasyon sabiti, $c$ ise çözelti konsantrasyonunu ifade etmektedir. Yukarıdaki eşitliğe göre $\log \Delta T_{\text {mak }}$ ve $\log R$ arasındaki lineer ilişkiden nükleasyon mertebesi, $m$, ve nükleasyon sabiti, $k_{\mathrm{n}}$, parametrelerinin değerleri belirlenebilmektedir. Ancak belirlenen bu değerlerin fiziksel önemlerinin ortaya konulamaması ve nükleasyon sabitinin kompleks birime sahip olması, ayrıca bu parametrelerin 3D nükleasyon teorisi ile yeterli bağlantısının bulunması problemlerini ortadan kaldırmak için self-consistent Nývlt - like eşitliği olarak adlandırılan yeni bir yaklaşım önerilmiştir [6]. Bu yaklaşıma göre maksimum aşırı soğuma oranı ile soğutma hızı arasındaki ilişki Eşitlik (2)'de gösterildiği gibidir.

$$
\frac{\Delta \mathrm{T}_{\mathrm{mak}}}{T_{0}}=\left(\frac{f}{K T_{0}}\right)^{\frac{1}{m}}\left(\frac{\Delta H_{d}}{R_{G} T_{n \dot{u} k}}\right)^{\frac{(1-m)}{m}} R^{\frac{1}{m}}
$$

$f$, çözünen konsantrasyonu ile hesaplanan sabit (nuclei/ hacim), $\Delta H_{d}$, çözünme 1 sısı, $\mathrm{R}_{\mathrm{G}}$ gaz sabitidir. Çözünme 1sısı, $\Delta H_{d}$ değeri ise Eşitlik (3)'de gösterilen van't Hoff denklemi kullanılarak belirlenebilir.

$\ln c^{*}=-\frac{\Delta H_{d}}{R_{G} T_{0}}+\frac{\Delta S_{d}}{R_{G}}$

$c^{*}$ incelenen bileşiğin mol fraksiyonudur.

$\ln \left(\frac{\Delta \mathrm{T}_{\text {mak }}}{\tau_{0}}\right)$ ve $\ln R$ ' nin lineer bağımlılı̆̆ ki denklemin her iki tarafının logaritması alınarak Eşitlik (4)'de görüldüğü gibi ortaya konulabilir.

$\ln \left(\frac{\Delta \mathrm{T}_{\max }}{\tau_{0}}\right)=\Phi^{\prime}-\beta \ln T_{0}+\beta \ln R=\Phi+\beta \ln R$

Eşitlik (4)'de ki,

$\beta=\frac{1}{m}$

$\Phi^{\prime}=\frac{(1-m)}{m} \ln \left(\frac{\Delta H_{d}}{R_{G} T_{\text {nük }}}\right)+\frac{1}{m} \ln \left(\frac{f}{K}\right)$

$\phi=\phi^{\prime}-\beta \ln \eta_{0}$

Eşitlik (4)'de görüldüğü üzere, $\ln \left(\frac{\Delta \mathrm{T}_{\mathrm{mak}}}{T_{0}}\right)-\ln R$ grafikleri çizildiğinde elde edilen doğrunun eğiminden $\beta$, kayımdan da $\Phi$ değerleri bulunur. Belirlenen değerlerden faydalanılarak; Eşitlik (5) ile görünür nükleasyon mertebesi, m ve Eşitlik (6) ve Eşitlik (7) kullanılarak yeni nükleasyon sabiti, $\mathrm{K}$ değerleri hesaplanır. Hesaplanan $\mathrm{m}$ değerine göre nükleasyon mekanizmasını ortaya koymak mümkün olmaktadır. Nükleasyon mertebesinin $\approx 3$ değerinin üzerinde olması, nüklei oluşumunun progresif nükleasyon mekanizması ile olduğunu, buna karşıllk düşük nükleasyon mertebesi değerleri ise nüklei oluşumunun ani nükleasyon sonucu gerçekleştiğini ortaya koymaktadır $[9,10]$.

Klasik üç boyutlu nükleasyon teorisine dayanan diğer bir yaklaşım da metastabil bölge genişliğinin değerlendirilmesi için kullanılmaktadır. Bu yaklaşıma göre $\left(\frac{\mathrm{T}_{0}}{\Delta \mathrm{T}_{\mathrm{mak}}}\right)^{2}$ gibi yazılabilmektedir.

$\left(\frac{\mathrm{T}_{0}}{\Delta \mathrm{T}_{\mathrm{mak}}}\right)^{2}=F-F_{1} \ln R=F(1-Z \ln R)$

$\left.\frac{T_{0}}{\Delta T_{\mathrm{mak}}}\right)^{2}$ - ln R grafiğinin kayımından F değeri, eğiminden Z değerleri hesaplanabilmektedir. F değeri Eşitlik (9)'de görüldüğü gibi yazılabilir.

$F=\frac{1}{Z B}\left(\frac{\Delta H_{d}}{R_{G} T_{n \mathrm{ukk}}}\right)^{2}$

Eşitlik (9)'da görülen $\mathrm{F}$ eşitliğini, $F_{1}=F Z$ denkleminde yerine koyduğumuzda Eşitlik (10) elde edilir.

$F_{1}=\frac{1}{B}\left(\frac{\Delta H_{d}}{R_{G} T_{\text {nuk }}}\right)^{2}$

$Z=\frac{F_{1}}{F}=\ln \left(\frac{f}{A T_{0}} \frac{\Delta H_{d}}{R_{G} T_{\text {nik }}}\right)$

Eşitlik (9)-(11) arasında görülen denklemler incelendiğinde, $\mathrm{F}$ ve $F_{1}$ değerlerinin, büyüme ortamında nüklei oluşumunun kinetiği ile ilgili kinetik parametre olan A ve termodinamik parametre olan B parametreleri ile ilişkili olduğu görülmektedir. Nükleasyon hızı, $/$ bu parametreler kullanılarak, klasik üç boyutlu nükleasyon teorisine dayanılarak, aşırı doygunluk, $\ln \mathrm{S}_{\text {mak }}$ cinsinden Eşitlik (12)'de görüldüğü gibi yazılabilir [11].

$J=A \exp \left[\frac{-B}{\left(\ln S_{\operatorname{mak}}\right)^{2}}\right]$

$B=\frac{16 \pi}{3}\left(\frac{\gamma}{k_{B}} \frac{\Omega_{\text {nik }}^{\frac{2}{3}}}{T^{3}}\right.$

$\gamma$ katı-sıvı ara yüzey enerjisi, $\Omega$ çözünen bir molekülün hacmi, $k_{\bar{B}}$ Boltzman sabitidir.

Safsızlıklar varlığında $F$ ve $Z$ değerleri Eşitlik (14) ve (15)'de görüldüğü gibi hesaplanabilmektedir [12-14].

$F=F_{0}\left(1+b_{1} \theta\right)$ 
$Z=Z_{0}\left(1+\alpha_{\theta f f} \theta\right)$

b sabiti Eşitlik (16)'da görüldüğü gibi yazılabilir.<smiles>[Al]=[W]=[W]</smiles>

z sabiti adsorplanan safsızlık iyonlarının/moleküllerinin kimyasal doğası ile ilişkili bir sabittir ve Eşitlik (17)'de görüldüğü gibi yazılabilir [13].

$\frac{\left(\gamma_{0}-\gamma_{i}\right)}{\gamma_{0} \theta}$

$\alpha_{\text {eff }}$ ise safsızlık etkinlik parametresidir ve Eşitlik (18)'de görüldüğü gibi yazılabilir. Bu eşitlikteki $A_{0}$ ve $A_{i}$ parametreleri, sirasiyla saf ortam ve katkı maddesi varlı̆̆ındaki parametrelerdir.

$\alpha_{\text {eff }}=\frac{\left(A_{0}-A_{i}\right)}{A_{0}}$

Safsızlıkların varlığı büyüme ünitelerinin büyüyen nükleiye entegrasyonunu engelleyebilir ya da destekleyebilmektedir. Eğer safsızlık etkinlik parametresi $\alpha_{\text {eff }}, 0 \leq \alpha_{\text {eff }}$ $\leq 1$ ise, safsızlıkların, büyüme ünitelerinin büyüyen nükleiye entegrasyonunu engellediği, $\alpha_{\text {eff }}<0$ ise bu entegrasyonun safsızlık partikülleri tarafından desteklendiği söylenebilmektedir [12].

$\theta$ ise safsızlıklardan etkilenen büyüyen nükleinin aktif bölgelerinin fraksiyonudur ve Eşitlik (19)'da görüldüğü gibi Langmuir adsorpsiyon izotermi ile tanımlanabilir.

$\theta=\frac{k_{L} c_{i}}{1+k_{L} c_{i}}$

Eşitlik (19)'da görülen, $c_{i}$ ssafsızlık konsantrasyonu ve $k_{z}$ ise Langmuir sabitidir. Langmuir sabiti, $k_{2}$ Eşitlik (20)'de görüldüğü gibi ifade edilebilir.

$k_{L}=\exp \left(-\frac{Q_{\text {diff }}}{R_{G} T}\right)$

$Q_{\text {diff }}$, diferansiyel adsorpsiyon 1sısıdır.

\section{BULGULAR VE TARTIŞMA}

Daha önceki çalışmamızda politermal yöntem kullanılarak Pentanoik ve Bütanoik asit varlığında 4 farklı soğutma hızı için ölçülen kalsiyum laktat sulu çözeltilerinin maksimum aşırı soğuma miktarlarının yağ asidi konsantrasyonuna karşı değişimi Şekil 2'de verilmiş̧tir. Şekil 2'den görüldüğü üzere, her iki yağ asidi için tüm soğutma hızlarında yağ asidi varlığında kalsiyum laktat sulu çözeltisinin metastabil bölge genişliği saf ortama göre artmıştır. Pentanoik asit varlığında metastabil bölge genişliğindeki artış pentanoik asit konsantrasyonu artışıly devam ederken, Bütanoik asit varlığıda ise, 25 ppm Bütanoik asit konsantrasyonuna kadar artmaya devam etmekte, daha yüksek Bütanoik asit konsantrasyonlarında ise düşme eğilimi göstermektedir.
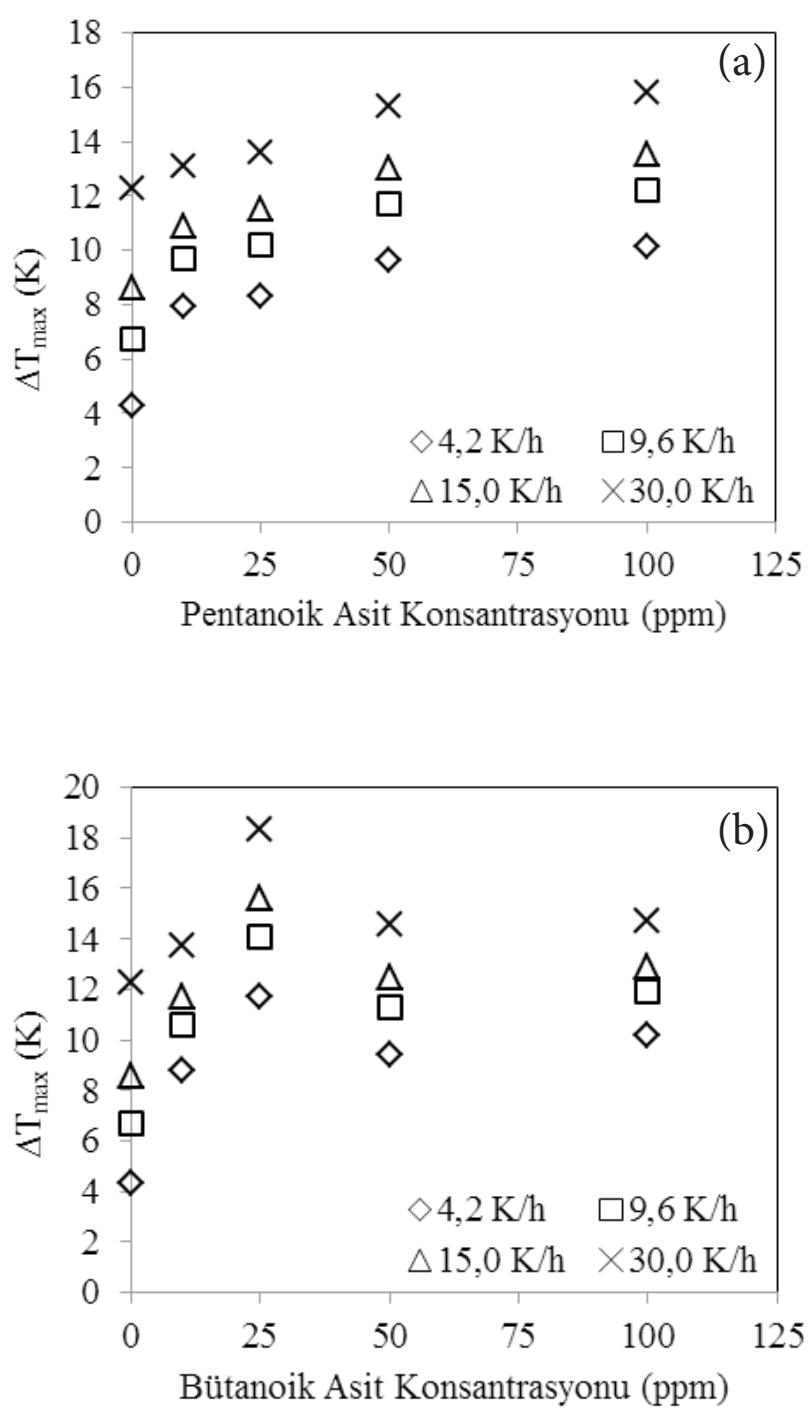

Şekil 2. Maksimum aşırı soğuma, $\Delta \mathrm{T}_{\text {max }}$ değerlerinin soğutma hızına ve (a) pentanoik ve (b) bütanoik asit konsantrasyonuna bağlı olarak değişimi

Self-consistent Nývlt-like eşitliği kullanılarak sonuçlar tekrar değerlendirilmiş ve $\ln \left(\Delta \mathrm{T}_{\max } / \mathrm{T}_{0}\right)$-Ln $\mathrm{R}$ grafikleri 
kullanılarak görünür nükleasyon mertebesi, m ve yeni nükleasyon sabiti, K değerleri hesaplanmıştır. Şekil 3-(a) ve (b) sırasıyla değişen Pentanoik ve Bütanoik asit konsantrasyonlarında $\ln \left(\Delta \mathrm{T}_{\max } / \mathrm{T}_{0}\right)-\mathrm{Ln} \mathrm{R}$ ilişkisini göstermektedir. Şekil 3 incelendiğinde, $\mathrm{Ln} R$ artışına karşıllık $\operatorname{Ln}\left(\Delta \mathrm{T}_{\max } / \mathrm{T}_{0}\right)$ değerlerinin lineer olarak arttığı görülmektedir.
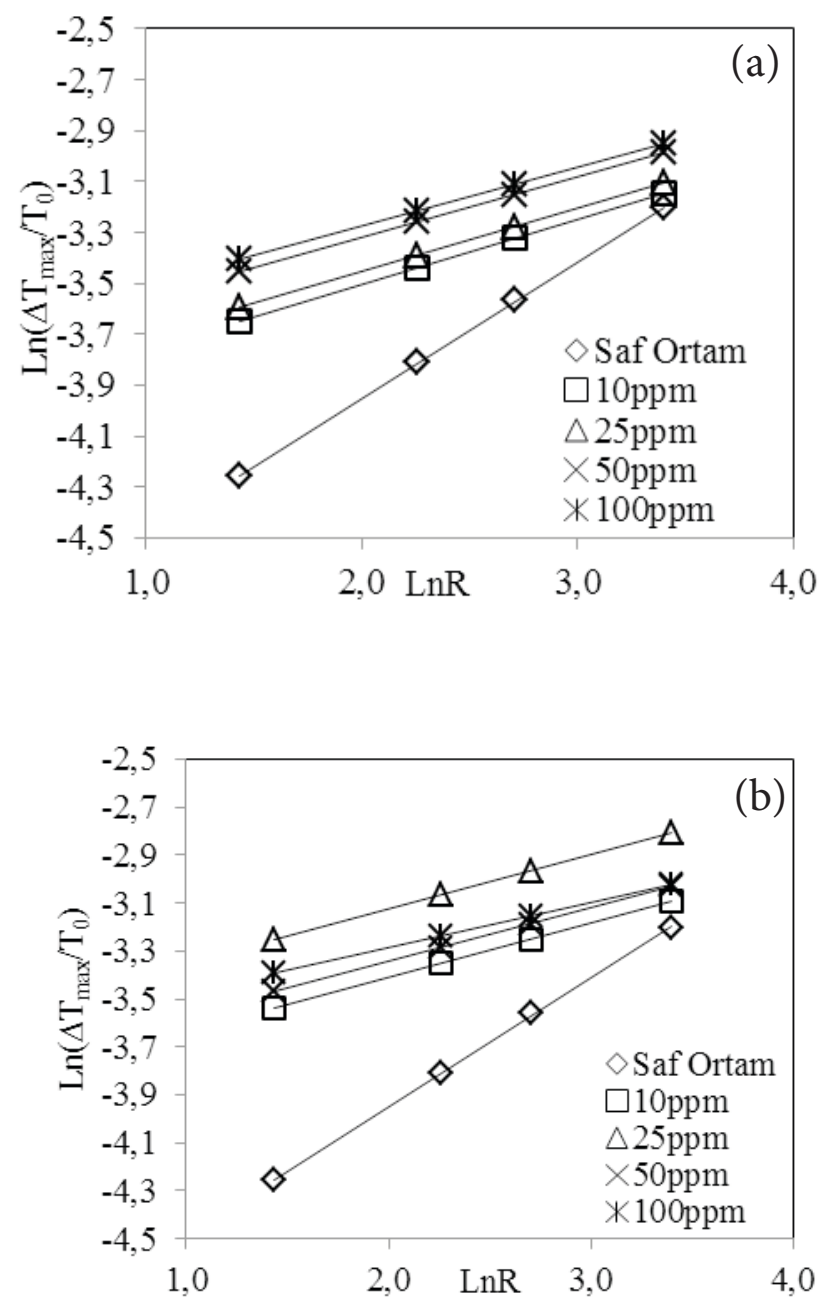

Şekil 3. Saf ortam, (a) pentanoik asit ve (b) bütanoik asit varlığında $\operatorname{Ln}\left(\Delta \mathrm{T}_{\max } / \mathrm{T}_{0}\right)-\mathrm{LnR}$ grafikleri

Şekil 3 'te görülen grafiklerin eğim ve kayımdan sırasıyla $\beta$ ve $\Phi$ değerleri ve bu değerlerden yararlanılarak, görünür nükleasyon mertebesi, $\mathrm{m}$ ve yeni nükleasyon sabiti, $\mathrm{K}$ değerleri hesaplanmıştır (Eşitlik (5)-(7)). Elde edilen sonuçlar Tablo 1'de sunulmuştur.
Tablo 1. Saf ortam, pentanoik ve bütanoik asitler varlığında hesaplanan $\mathrm{m}$ ve $\mathrm{K}$ değerleri

\begin{tabular}{|c|c|c|c|c|c|c|c|}
\hline \multirow[b]{2}{*}{ Ortam } & \multirow{2}{*}{$\begin{array}{c}\text { Yağ } \\
\text { Asit } \\
\text { Kons. } \\
\text { (ppm) }\end{array}$} & \multicolumn{6}{|c|}{ Self-Consistent Nývlt - like Denklemi } \\
\hline & & $\beta$ & $\mathrm{m}$ & $-\Phi$ & $-\Phi^{\prime}$ & $\begin{array}{c}\mathrm{K}\left(\mathrm{x} 10^{30}\right. \\
\left.\mathrm{m}^{-3} \cdot \mathrm{h}^{-1}\right)\end{array}$ & $\mathrm{R}^{2}$ \\
\hline $\begin{array}{l}\text { Saf } \\
\text { Ortam }\end{array}$ & 0 & 0,5360 & 1,8657 & 5,0222 & 1,9596 & 0,2044 & 0,9998 \\
\hline \multirow{4}{*}{$\begin{array}{l}\text { Pen- } \\
\text { tanoik } \\
\text { Asit }\end{array}$} & 10 & 0,2566 & 3,8971 & 4,0176 & 2,5515 & 5,5400 & 1,0000 \\
\hline & 25 & 0,2517 & 3,9730 & 3,9571 & 2,5190 & 5,2588 & 1,0000 \\
\hline & 50 & 0,2366 & 4,2265 & 3,7925 & 2,4406 & 4,8495 & 1,0000 \\
\hline & 100 & 0,2296 & 4,3554 & 3,7328 & 2,4209 & 5,0104 & 1,0000 \\
\hline \multirow{4}{*}{$\begin{array}{l}\text { Büta- } \\
\text { noik Asit }\end{array}$} & 10 & 0,2264 & 4,4170 & 3,8636 & 2,5700 & 10,4636 & 1,0000 \\
\hline & 25 & 0,2260 & 4,4248 & 3,5756 & 2,2843 & 2,8522 & 1,0000 \\
\hline & 50 & 0,2230 & 4,4843 & 3,7899 & 2,5157 & 8,7311 & 1,0000 \\
\hline & 100 & 0,1882 & 5,3135 & 3,6635 & 2,5882 & 30,3439 & 1,0000 \\
\hline
\end{tabular}

Tablo 1'den görüldüğü üzere yağ asitleri varlığında elde edilen $\mathrm{K}$ değerlerinin saf ortama göre artış gösterdiği açıkça görülmektedir. Nükleasyon mertebesinin $(\mathrm{m})$, yağ asitleri varlığında belirgin şekilde arttığı ve bu artışın konsantrasyon artışı ile her iki yağ asiti varlığında da devam ettiği görülmektedir. Saf ortamda elde edilen $\mathrm{m}=1,8657$ değeri, saf ortamda nüklei oluşumunun ani nükleasyon mekanizması ile gerçekleştiği, daha sonra oluşan nükleilerin büyüyüp, kristal olarak geliştiği ve çözelti hacminde üç boyutlu heterojen nükleasyonun ve/veya ikincil nükleasyonun olduğunun bir göstergesi olduğu söylenebilir [10]. Buna karş1lık, Pentanoik ve Bütanoik yağ asitleri varllğğnda ise $\mathrm{m}$ değerlerinin 3 'ten büyük olması, nüklei oluşum mekanizmasının değiştiği ve nüklei oluşumunun progresif nükleasyon mekanizması ile gerçekleştiğini göstermektedir. Dolayısıyla saf ortamda tüm nükleiler aynı anda oluşup, ardından yeni nüklei oluşumu olmadan büyüme gerçekleşirken, bu yağ asitleri varlığında, yeni kristal nükleilerinin, büyüyenlerin varlığında sürekli olarak oluştuğu söylenebilmektedir. Yağ asitleri varlığında nükleasyon mertebesinin saf ortama göre ortalama 2,5 kat arttığ1 görülmekle birlikte, yağ asidi konsantrasyon artışı ile çok etkin olmasa da mertebenin artmaya devam ettiği tespit edilmiştir. Ani nükleasyon mekanizması dikkate alındığında; çözeltinin belirli sayıda aynı boyutta kristalitlerden oluşacağı söylenebilirken, progresif nükleasyon sonucunda herhangi bir zaman diliminde, çözelti içerisinde farklı boyutlarda kristaller olacağı söylenebilmektedir[10,15,16]. Katkı maddeleri varlığında ortaya konulan bu nükleasyon mekanizmasındaki değişim, kalsiyum laktatın istenmeyen kristalizasyonun ve ilaç sektöründe kullanılmak üzere üretilecek olan kalsiyum laktatın tane boyutunun, 
Pentanoik ve Bütanoik yağ asitlerin konsantrasyonlarındaki değişim ile kontrol altına alınabileceği söylenebilmektedir.

Klasik üç boyutlu nükleasyon teorisine dayanan diğer bir yaklaşım ile katkı maddelerinin etkisi daha ayrıntılı olarak incelenebilmektedir. Bu amaçla Eşitlik (8)'e göre, $\left(\frac{T_{0}}{\Delta T_{\max }}\right)^{2}$ - ln R grafikleri çizilmiş ve elde edilen sonuçlar Şekil 4'de verilmiştir.
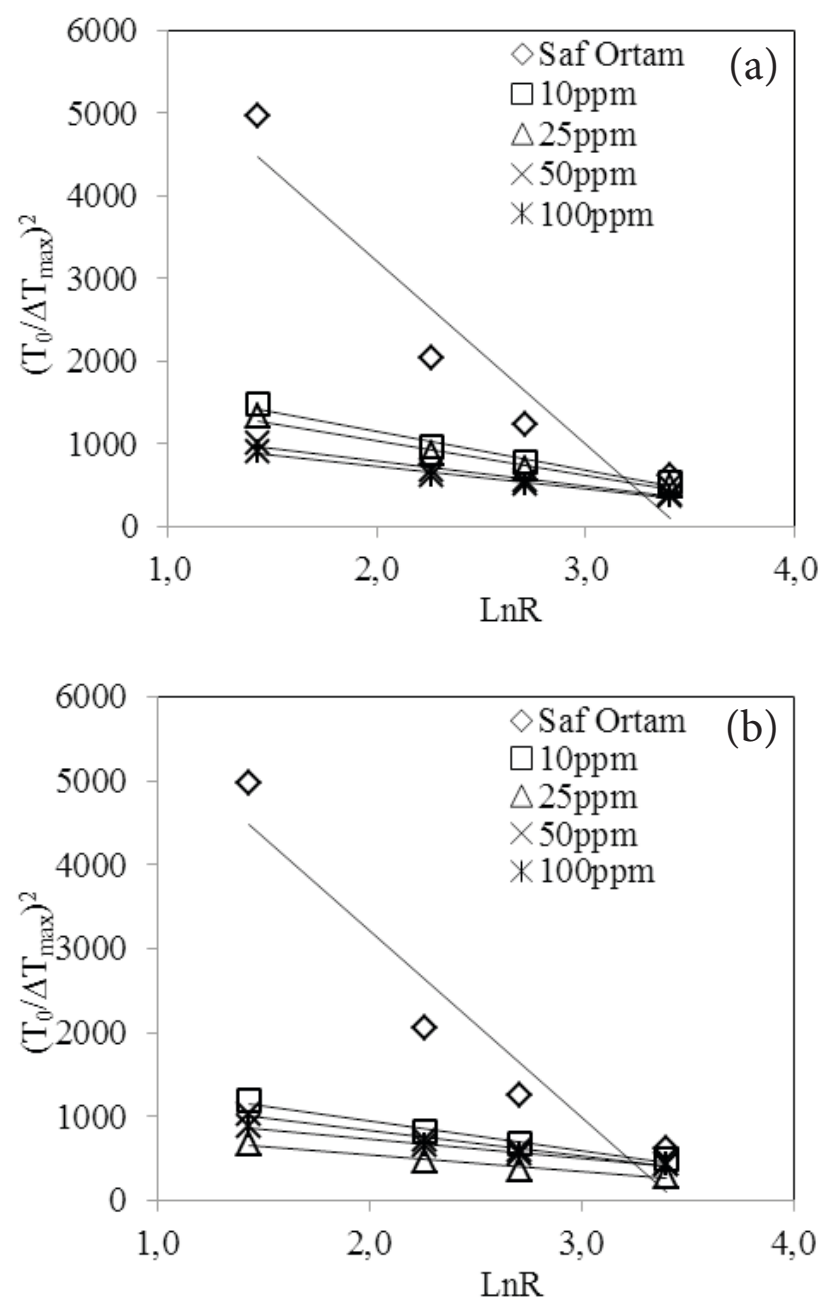

Şekil 4. Saf ortam, (a) pentanoik asit ve (b) bütanoik asit varlığında $\left(\mathrm{T}_{0} / \Delta \mathrm{T}_{\max }\right)^{2}-\mathrm{LnR}$ grafikleri

Şekil 4'de görüldüğü üzere saf ortam ve her iki yağ asidi varlığında $\mathrm{Ln} R$ değerlerindeki artış ile $\left(\mathrm{T}_{0} / \Delta \mathrm{T}_{\max }\right)^{2}$ değerlerinin azaldığı görülmektedir. Şekil 4'de sunulan grafiklerin kayım ve eğiminden sırasıyla $F$ ve $F_{1}$ değerleri bulunmuş ve hesaplanan $\mathrm{F}_{1} / \mathrm{F}$ oranları, $\mathrm{Z}$ değerleri olarak Tablo 2'de sunulmuştur.
Tablo 2. F, Z ve regrasyon katsayısi, $\mathrm{R}^{2}$ değerleri

\begin{tabular}{lccccc}
\hline \multirow{2}{*}{ Ortam } & $\begin{array}{c}\text { Yağ Asit } \\
\text { Kons. }\end{array}$ & \multicolumn{4}{c}{$\begin{array}{c}\text { 3D Nükleasyon Teorisine Dayanan } \\
\text { Yaklaşım }\end{array}$} \\
\cline { 3 - 6 } & $($ ppm) & $\mathrm{F}$ & $\mathrm{F}_{1}$ & $\mathrm{Z}$ & $\mathrm{R}^{2}$ \\
\hline Saf Ortam & 0 & 7679,40 & 2229,10 & 0,2903 & 0,9095 \\
\hline \multirow{3}{*}{ Pentanoik Asit } & 10 & 2114,60 & 479,73 & 0,2269 & 0,9753 \\
& 25 & 1894,40 & 426,20 & 0,2250 & 0,9761 \\
& 50 & 1409,80 & 308,59 & 0,2189 & 0,9787 \\
& 100 & 1207,70 & 274,35 & 0,2272 & 0,9799 \\
\hline Bütanoik Asit & 10 & 1662,10 & 356,55 & 0,2145 & 0,9804 \\
& 25 & 935,05 & 200,42 & 0,2143 & 0,9805 \\
& 50 & 1445,00 & 307,79 & 0,2130 & 0,9810 \\
& 100 & 1206,40 & 236,45 & 0,1960 & 0,9862 \\
\hline
\end{tabular}

Tablo 2'den görüldüğü üzere, Pentanoik asit ve Bütanoik asit varlığında $\mathrm{F}$ ve $\mathrm{Z}$ değerlerinin saf ortamda elde edilen değerlere kıyasla belirgin şekilde azaldığı görülmektedir. Bileşiklerin sabit bir özelliği olan $\mathrm{Z}$ değerinin $\left(\mathrm{Z}=\mathrm{F}_{1} / \mathrm{F}\right)$ kararlı nüklei oluşum kinetiği ile bağlantılı olan $J_{0}$ kinetik parametresine, $\mathrm{F}$ değerinin ise $\mathrm{B}$ sabitinin yanı sıra $J_{0}$ kinetik parametresinin değerine bağlı olduğu literatürde belirtilmiştir [17]. Bunun yanında $Z$ değerinin bir sistemde nükleasyonu engelleyen ya da destekleyen aşı kristallerinin ve safsızlıkların varlığına ve karıştırma hızı gibi çeşitli faktörlere de bağlı olarak değişebileceği vurgulanmıştır [7]. Z değerindeki değişim, kritik boyuttaki 3D kararlı nükleilerin görünür hale gelmelerindeki büyüme hızlarındaki farktan kaynaklı olabileceği ve kararlı nükleilerin büyüme hızları ne kadar büyük ise bu sabitin değerinin o kadar büyük olacağ1 da yine literatürde belirtilmiştir [7]. Buna göre Tablo 2'de de görüldüğü gibi hesaplanan $\mathrm{Z}$ değerlerinin Pentanoik ve Bütanoik asit varlığında düşme eğilimi göstermesi, bu yağ asitleri varlığında kalsiyum laktat pentahidrat kararlı nükleilerinin büyüme hızının da düşme eğiliminde olacağının göstergesidir. Hesaplanan Z değerlerinin kalsiyum laktat çözeltisindeki yağ asiti konsantrasyonuna bağlı değişimi Şekil 5'de sunulmuştur.

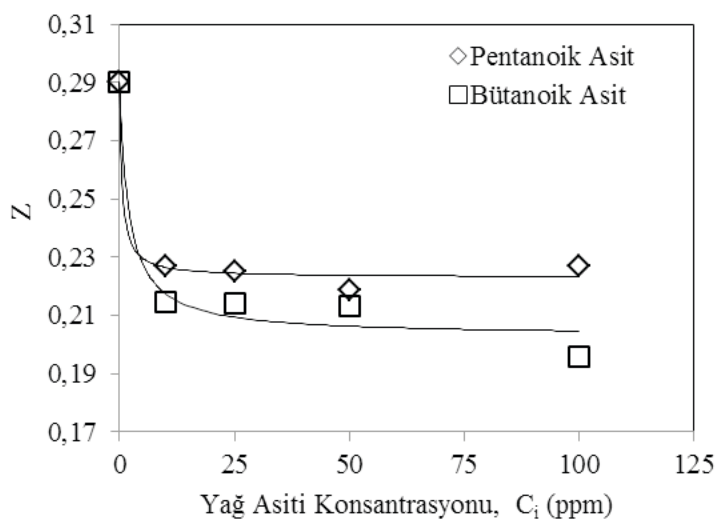

Şekil 5. Kalsiyum laktat çözeltisindeki yağ asiti konsantrasyonuna karşı Z değerleri 
Şekil 5'de gösterilen Z-yağ asit konsantrasyonu ilişkisi kullanılarak $\alpha_{\text {eff }}$ değerleri, Pentanoik ve Bütanoik asit varlığında surasiyla $-0,2318$ ve $-0,3008$ olarak bulunmuştur. Elde edilen negatif $\alpha_{s f f}$ değerleri her iki yağ asitinin çözünen moleküllerin gelişen 3D nükleiye entegrasyonunu desteklediğini göstermektedir. Ayrıca bu değerler karşılaştırıldığında bu entegrasyonda Bütanoik asitin Pentanoik asitten daha etkin olduğu söylenebilmektedir. Literatürde $\alpha_{\text {eff }}$ değerlerinin, kullanılan katkı maddelerinin diferansiyel adsorpsiyon 1 sısı, $\mathrm{Q}_{\text {diff }}$ değerleri ile ilişkili olduğu ve düşük $\mathrm{Q}_{\text {diff }}$ ve $\left|\alpha_{\text {eff }}\right|$ değerlerinin de bu katk1 maddelerinin nükleasyonu arttırıcı etkisinin düşük olacağı belirtilmektedir [14]. Dolayısıyla, her iki katkı maddesinin nükleasyonun arttırıcı etkileri, $\left|\alpha_{\text {eff }}\right|$ değerleri dikkate alınarak kıyaslandığında, Pentanoik asitin nükleasyonu arttırıcı etkisinin Bütanoik asitten daha düşük olduğu söylenebilmektedir.

\subsection{Sonuç ve Değerlendirmeler}

Elde edilen sonuçlar, kalsiyum laktat sulu çözeltilerinin metastabil bölge genişliğindeki artışın, katkı maddelerinin çözelti içindeki nükleilerin büyüyen yüzeylerine adsorplanması ile açılanabileceğini göstermektedir. $\mathrm{Bu}$ da, Pentanoik ve Bütanoik asit varlığında kristalizasyon prosesinin kontrolünün daha kolay olacağının göstergesidir. Katkı maddesi olarak kullanılan yağ asitleri varlığında nüklei oluşum mekanizmasının değiştiği tespit edilmiştir. Saf ortamda nüklei oluşumu, ani nükleasyon mekanizmasıyla, yağ asitleri varlığında ise progresif nüklei oluşum mekanizmasi ile gerçekleşmektedir. Dolayısıyla saf ortamda nükleiler kristalizasyon prosesinin başlangıcında tek seferde oluşup, ardından büyür ve kristalleri oluştururlar, yağ asitleri varlığında ise nüklei oluşumu uzun zamana yayılır ve varolan büyüyen nükleilerin varlığında sürekli nüklei oluşumu söz konusudur. Sonuç olarak, saf ortamda kristalizasyon prosesinde mevcut nükleilerin büyüme basamağ kazanır iken, yağ asitleri varlığında nükleasyon ve büyüme basamaklarının her ikisi de kristalizasyonun kontrolü açısından önemlidir. Katkı maddeleri varlığında hesaplanan $\mathrm{Z}$ değerlerindeki azalma ise kalsiyum laktat pentahidrat kararlı nükleilerinin büyüme hızının da düşme eğiliminde olacağını göstermektedir. Ayrıca $\mathrm{Z}$ değerlerinden yararlanılarak tespit edilen $\alpha_{\text {eff }}$ değerleri, her iki yağ asitinin çözünen moleküllerin gelişen 3D nükleiye entegrasyonunu desteklediğini göstermektedir. Yağ asitleri varlığında tespit edilen bu deneysel sonuçlar ve onların iki farklı yaklaşıma göre teorik yorumlamaları kalsiyum laktatın peynir yüzeyindeki istenmeyen kristalizasyonunun geciktirilmesinin ve/veya engellenmesinin ve ilaç sektöründe kullanılacak olan kalsiyum laktatın istenilen nitelikte elde edilmesinin yağ asitlerinin konsantrasyonlarının kontrolü ile sağlanabileceğini ortaya koymaktadır.

\section{KAYNAKLAR}

[1] Suda, R., Suzuki, T., Takiguchi, R., Egawa, K., Sano, T., \& Hasegawa, K., (2006). The Effect of Adding Calcium Lactate to Xylitol Chewing Gum on Remineralization of Enamel Lesions. Caries Research, 40(1), 43-46.

[2] Luna-Guzman, I., \& Barrett, D.M., (2000). Comparison of Calcium Chloride and Calcium Lactate Effectiveness in Maintaining Shelf Stability and Quality of Fresh-Cut Cantaloupes. Postharvest Biology and Technology, 19(1), 61-72.

[3] Bolhuis G.K., Eissens A.C., \& Zoestbergen E., (2001). DC Calcium Lactate, a New Filler-Binder for Direct Compaction of Tablets. International Journal of Pharmaceutics, 221(1-2),77-86.

[4] Agarwal S., Sharma K., Swanson B.G., Yüksel, G.Ü., \& Clark S., (2006). Nonstarter Lactic Acid Bacteria Biofilms and Calcium Lactate Crystals in Cheddar Cheese. Journal of Dairy Science, 89(5), 1452-66.

[5] He, S., Oddo, J.E., \& Tomson, M.B., (1994). The Inhibition of Gypsum and Barite Nucleation in $\mathrm{NaCl}$ Brines at Temperatures from 25 to $90^{\circ} \mathrm{C}$. Applied Geochemistry, 9(5), 561-567.

[6] Sangwal, K., (2009). A novel self-consistent Nyvlt-like equation for metastable zone width determined by the polythermal method. Crystal Research and Technology, 44(3), 231-247.

[7] Sagwal, K., (2009). Novel Approach to Analyze Metastable Zone Width Determined by the Polythermal Method: Physical Interpretation of Various Parameters. Crystal Growth \& Design, 9(2), 942-950.

[8] Kıran-Yıldırım B., Sayan, P., \& Titiz-Sargut, S. (2014, Eylül). Kalsiyum Laktatın Metastabil Bölge Genişliği Üzerine Yă̆ Asitleri Etkisinin Incelenmesi. A. Aşkın, F. Tümsek, A. Ç1tak, B. Karabacakoğlu \& C. Aydın Şamdan (Ed.). XI. Ulusal Kimya Mühendisliği Kongresi, Eskişehir (618-619). Eskişehir: Eskişehir Osmangazi Üniversitesi Kimya Mühendisliği.

[9] Sangwal, K., (2011). Recent developments in understanding of the metastable zone width of different solute-solvent systems. Journal of Crystal Growth, 318(1), 103-109.

[10] Kashchiev, D., Borissova, A., Hammond, R. B., \& Roberts, K. J., (2010). Effect of cooling rate on the critical undercooling for crystallization. Journal of Crystal Growth, 312(5), 698-704.

[11] Wang L., Feng H., Peng J., Dong N., Li W., \& Dong Y., (2015). Solubility, Metastable Zone Width and Nucleation Kinetics of Sodium Dichromate Dihydrate. Journal of Chemical \& Engineering Data, 60(1), 185-191.

[12] Sagwal, K., (2009). Effect of impurities on the metastable zone width of solute-solvent systems. Journal of Crystal Growth, 311(16), 4050-4061.

[13] Qian , Y., Lu, G., Sun, Y., Song, X., \& Yu, J., (2014). Metastable zone width of $\mathrm{SrCl}_{2} \cdot 6 \mathrm{H}_{2} \mathrm{O}$ during cooling crystallization. Crystal Research and Technology, 49(1), 78-83.

[14] Sagwal, K., (2010). On the effect of impurities on the metastable zone width of phosphoric acid. Journal of Crystal Growth, 312(22), 3316-3325. 
[15] Kashchiev, D., Borissova, A., Hammond, R.B., \& Roberts, K. .J., (2010). Dependence of the Critical Undercooling for Crystallization on the Cooling Rate. The Journal of Physical Chemistry B, 114 (16), 5441-5446.

[16] Kashchiev D., (2000). Nucleation: basic theory with applications, Butterworth-Heinemann, Oxford.
[17] Mielniczek-Brzóska, E., (2014). Effect of sample volume on the metastable zone width of potassium nitrate aqueous solutions. Journal of Crystal Growth, 401 (1), 271-274. 